\title{
INVESTIGATING THE VIABILITY OF THE CHARITY BASED MODEL OF ISLAMIC MICROFINANCE FOR ERADICATING THE IMPACT OF COVID-19 ON SOCIAL WELLBEING IN NIGERIA: A DESCRIPTIVE ANALYSIS
}

\author{
${ }^{1}$ Abdullateef Abdulqadir Maikabara, ${ }^{2}$ Abdulmajeed M.R. Aderemi, ${ }^{3}$ Sri Maulida \\ ${ }^{1}$ IIUM Institute of Islamic Banking and Finance (IIiBF), International Islamic University \\ Malaysia. \\ ${ }^{2}$ Faculty of Business and Management, University Sultan Zainal Abidin, Terengganu Malaysia. \\ ${ }^{3}$ Faculty of Economic and Business, Universitas Lambung Mangkurat, Indonesia. \\ Corresponding author: Abdulqadirm2018@gmail.com
}

\begin{abstract}
The coronavirus known as (Covid-19) pandemic has posed a significant impact on social and economic sectors as many institutions and individuals face difficulties in meeting their needs. Over the years, Islamic microfinance has shown positively significant effects on socio-economic development. Recently, it is gaining strong momentum in the financial ground in Nigeria. The research aims to examine the perception of Islamic microfinance on social wellbeing as a relief measure to eradicate the impact of Covid-19. A total of 100 respondents were involved, and descriptive statistical analysis was used to measure the perception. The findings revealed that the charity-based model is viable for relieving people's social wellbeing. The paper recommended proactive and constructive measures in implementing the model to generate funds for fighting against the outbreak and ensure social stability.
\end{abstract}

Keywords: Charity, Islamic microfinance, Covid-19, Social wellbeing, Nigeria.

\section{INTRODUCTION}

Microfinance is a financial institution that provides financial services to underprivileged individuals and low-income groups. Typically, microfinance aims to evolve around socioeconomic development, especially poverty eradication and financial inclusion. According to Muhammad and Mamman (2017), microfinance as a financial institution that supports unprivileged poor and low-income earners who have no access to financial services, unlike in conventional bank which neglected them. In contrast, Islamic microfinance is an Islamic version of the conventional counterpart which serves the low-income group though it denotes the provision of financial services based on Islamic values that promote fairness and justice. In addition, both conventional and Islamic microfinance have similarities in terms of developmental and social goals and financial inclusion, partnership, and entrepreneurship involvement by the poor people (Obaidullah, M. \& Khan, T, 2008; Obaidullah, 2008; Maikabara, 2020).

Meanwhile, the evolution of microfinance has been existence since the 1970s as it started in Bangladesh by Muhammad Yunus, who established Gramen Bank and invented the Gramen model. The success of this initiative led to the great attention of many governmental and nongovernmental organizations across the world to replicate it as it has served the wellbeing of the poor (Al-Shami S.S.A, Adbul Majid I.B, Abdul Rashid N. \& Abdul Hamid M.S.R, 2013). As a result of this, various Islamic and conventional microfinance institutions are established to 
provide financial services to the poor and low-income groups based on several schemes, be it credit, saving, equity, and others more.

Moreover, in the context of Nigeria, the coronavirus (Covid-19) pandemic has posed a significant effect on socio-economic development as many institutions are in financial crisis as individuals, especially the poor, find it difficult to facilitate their basic needs. However, many studies have indicated that Islamic microfinance would significantly contribute to socio-economic development (Irobi, 2008; Muahmmad A.D \& Muhammad A, 2013; Muhammad T \& Mamman. D., 2017; Abdul Khalid, S.N \& Kamaruddin, S.S, 2019; Maikabara, 2020), Hence, as every economic segment has been affected by the coronavirus (Covid-19) outbreak by slowing down the business operation, which attributes economic crisis and eventually triggers the social wellbeing across the globe. Thus, Islamic microfinance has an architecture for facilitating the business operation of the small and medium enterprises (SMEs) and exercise the wellbeing of the poor, and low-income households would play a prominent role in fighting against the negative of the outbreak on social wellbeing. Therefore, this study attempts to investigate the perception of the Islamic charity based microfinance model on the impact of the Covid-19 on social wellbeing.

\subsection{Overview of Microfinance}

The concept of Microfinance can have been expressed in different ways based on various objectives of financing attributing to the needs and wants of the beneficiaries. Wanchoo (2007) defines microfinance as "any activity that includes the provision of financial services such as credit, savings, and insurance to low-income individuals who either fall below the nationally defined poverty line or fall just above that, with the goal of creating social value." According to Morduch (1999) as cited by Muhammad \& Mamman (2017), microfinance denotes a financial institution that supports low-income earners who have no access to financial services.

Technically, Al-Shami, Adbul, Abdul Rashid. \& Abdul Hamid (2013) contended that the definition of microfinance includes both financial and social intermediation. On the other hand, Obaidullah (2008) categorized the forms of microfinance facilities into various services, which include micro-credit, micro-equity, micro-savings, micro-transfer, and micro-insurance.

On the contrary, Islamic microfinance is an Islamic version of microfinance that facilitates the provision of financial services to poor and low-income groups, which are entirely or partially excluded in the conventional microfinance system from exercising financial services due to their low economic status. Meanwhile, there are several differences which distinct Islamic microfinance from its conventional counterpart in both operation and scheme such as religious element, sources of fund, instruments, and ethical norms (Obaidullah, 2008).

Historically, the modern concept of microfinance can be traced back to the 1970s of the Grameen Bank of Bangladesh established by Professor Muhammad Yunus. Interestingly, after then, many governmental and non-governmental organizations across the globe work towards replication of the initiative due to its tremendous contribution to the wellbeing of the people (AlShami S.S.A, Adbul Majid I.B, Abdul Rashid N. \& Abdul Hamid M.S.R, 2013).

According to Mirghani (2011) as cited by Muhammad \& Mamman (2017), Islamic microfinance at that time is quite small in Latin America and South Asia as it aimed at the maximization of social welfare, unlike in the conventional banking system. Small loans were granted to millions of people without any condition such as built up assets, collateral, or insurance. Hence, since the 1970s, remarkable development has been seen worldwide in the sector. As of late, more than 25 million poor individuals are served by more than 7000 micro-lending organizations (MLOs) everywhere around the globe (Muhammed A.D \& Hassan Z., 2008). 
Moreover, the significant positive roles played by the Islamic microfinance for many years and the attention given to realizing the sustainable social development by global researchers and policymakers in relation to the economic growth result from the great momentum for the Islamic microfinance sector as an alternative tool to serve the needs of the economy and social wellbeing across the world.

\subsection{Islamic Microfinance Models}

It is imperative to note that there is no much difference in the operational models that have been adopted and used by the Islamic and conventional microfinance ever since the initiation of microfinance. However, the difference, as addressed earlier, lies in religious compliance, instruments, and ethical consideration. Thus, the models are usable as an Islamic microfinance model as long as there is no element that contravenes the paradigm of Islamic principles and values (Obaidullah, 2008). Here, the generally adopted and used over the years shall be enumerated as according to Obaidullah (2008) as cited by (Maikabara, 2020).

Grameen Bank model: is a group-based financing model that was established by Professor Muhammad Yunus, who established Grameen Bank in Bangladesh in the 1970s. As an alternative tool, the model works to mitigate default and delinquency risk.

Village Bank Model: This model involves executing agencies that set up individual village banks, manages an account with 30 to 50 individuals, and gives external capital for onward financing to individuals.

Credit Union model: The main element in this model is the idea of mutuality and mutual financial cooperative owned and constrained by its membership. The credit union mobilizes savings, gives loans to beneficial and fortunate purposes. This can be found in Asia, especially Sir Lanka and Islamic financial cooperatives in Indonesia called Baitul Maal wat Tamweel (BMT) that provide charity-based not-for-profit as well as for-profit financing.

Self-Help Groups (SHGs): This model forms around 10 to 15 members having the same income level, and they pool funds together as saving for lending. The SHGs are promoted by NGOs to wind up self-sustaining institutions.

Furthermore, Obaidullahi, on the other hand, proclaimed three pure Islamic based microfinance models which are the not for profit-based which uses charity modes such as Sadaqah, Waqf, Zakat, and Qardul-Hassan, and market or profit-based models, and the second model is market or for-profit model that implies to micro-Credit using Murabaha, Istisnah and Salam, micro-Leasing using Ijarah and micro-equity using the mode of Mudaraba and Musharakah. The last category is the integration of both not-for profit and for profit model known as a composite model that incorporates two or more charity and market-based together. This model seems to be more productive and sustainable than promoting one of the other two models as the poor, and low income can potentially work towards financial independence as well as they can contribute to the economic development

\subsection{The impact of the Coronavirus (Covid-19) pandemic}

Since then, the virus has been touring the world and turned to a natural disaster that has never been witnessed by the whole world in recent decades. On 30 January 2020, the World Health Organization recognized the occurrence as an Emergence Public Health issue of International Concern, which was later on March 11, 2020, declared as a pandemic. According to WHO (2020), as of $20^{\text {th }}$ of June 2020, not less 8.95 million cases of COVID-19 have been reported in 216 countries across the six continents, resulting in more than 400,000 deaths reported to WHO.

In the African continent, the first case recorded was in Egypt on Friday, Feb 15, 2020. It was said to be through a patient who is not from Egypt and didn't show any symptoms of illness (D.W., 
2020). However, when the world seems to be gaining control over the virus, Nigeria's cases begin to be escalated. The COVID-19 found its way to Nigeria through an Italian citizen who has contaminated the virus before entering the country and later on infects a Nigerian citizen who came in contact with him. (Vanguard, 2020). The virus, due to its speed of spreading, then transmit to other people in Lagos- the country's commercial nerve center- and from there escalate to other parts of the country. As of 21 June 2020, the Nigeria Center for Diseases Control (NCDC) confirmed 20244 cases with 518 deaths (NCDC, 2020).

The COVID-19 pandemic has not only been causing death but has also had a bad impact on people's social wellbeing and make life more difficult for ordinary people all over the world. Apparently, the pandemic has had a far-reaching impact on the social wellbeing of people, households, and businesses in Nigeria. (Fehintola \& Fehintola, 2020) stressed that the impact of Covid-19 on youths, adolescents, and married couples in Nigeria is serious in which their wellbeing has been affected and cannot be inverted as a result of corrupt government who supposed to provide for its poor citizen but instead hold the money that was donated by a philanthropist, and this adds more to the hardship of the poor common people who are breathing from hand to mouth. The 14-days nationwide stay-at-home total lockdown, which was officially imposed launched on 30th March 2020, had a serious impact on a business as the education sector, banking sector, aviation sector, civil service sector, and major food market were closed (Ozili, 2020). The study shows that a certain percentage of people in Nigeria have been reported that their wellbeing had been obstructed by anxiety, stress, and over-worried as a result of the pandemic (Effiong et al., 2020).

\section{METHODOLOGY}

This study adopts a quantitative research approach using a questionnaire to collect data from beneficiaries of microfinance banks in Ilorin, the capital city of Kwara state. Meanwhile, a simple random sampling technique was used by selecting 100 sample size. Therefore, 100 questionnaires were distributed to microfinance clients between the ages of 18 to 61 . The data were analyzed on SPSS, version 25 , using a descriptive statistical analysis method, which comprises of frequency, percentages, mean and standard deviation.

\section{FINDINGS AND DISCUSSION}

\subsection{Presentation of the findings}

\subsubsection{Demographic profile}

Table 1 Gender

\begin{tabular}{|l|l|l|}
\hline Item & Frequency & Percentage $\%$ \\
\hline Male & 39 & 35.1 \\
\hline Female & 61 & 56.5 \\
\hline Total & 100 & 100 \\
\hline
\end{tabular}

According to the table, the female respondents form the highest response percentage, while the male respondents form a lower percentage of (36.1\%).

Table 2 Age

\begin{tabular}{|l|l|l|}
\hline Item & Frequency & Percentage $\%$ \\
\hline $18-30$ & 36 & 33.3 \\
\hline
\end{tabular}




\begin{tabular}{|l|l|l|}
\hline $31-35$ & 15 & 13.9 \\
\hline $36-40$ & 33 & 30.6 \\
\hline $45-60$ & 14 & 13.0 \\
\hline $61-$ Above & 2 & 1.9 \\
\hline Total & 100 & 100 \\
\hline
\end{tabular}

The table indicated that the respondents' ages range between 18 to 60 as the respondents' age between 18 to 30 were the majority having a percentage of (33.3) whereas the least were those who fall within the age of 60 and above amount for a percentage of (1.9).

Table 3 Marital Status

\begin{tabular}{|l|l|l|}
\hline Item & Frequency & Percentage $\%$ \\
\hline Single & 19 & 17.6 \\
\hline Married & 79 & 73.1 \\
\hline Divorced & 2 & 1.9 \\
\hline Total & 100 & 100 \\
\hline
\end{tabular}

This table revealed that the married respondents have the highest participation rate as their response accounted for a frequency of $79(73.1 \%)$ compared to other items as the frequency of the divorced respondents amounted to $2(1.9 \%)$.

Table 4 Religion

\begin{tabular}{|l|l|l|}
\hline Item & Frequency & Percentage\% \\
\hline Islam & 71 & 65.7 \\
\hline Christianity & 29 & 26.9 \\
\hline Total & 100 & 100 \\
\hline
\end{tabular}

The religion of the respondent indicated that Muslim respondents were the majority and accounted for $71(65.7 \%)$, whereas those from Christianity religion were the least, accounting for 29 $(26.9 \%)$.

Table 5 Geographical Region

\begin{tabular}{|l|l|l|}
\hline Item & Frequency & Percentage $\%$ \\
\hline Rural & 6 & 5.6 \\
\hline Urban & 94 & 87.0 \\
\hline Total & 100 & 100 \\
\hline
\end{tabular}

The statistic of the geographical region as depicted in the table shown that majority of the respondents were from the urban area, accounted for $94(87 \%)$ while the least of the respondents were from the rural area accounted for $6(5.6 \%) .6$

Table 6 Education Level

\begin{tabular}{|l|l|l|}
\hline Item & Frequency & Percentage\% \\
\hline High School & 12 & 11.1 \\
\hline Diploma/NCE & 46 & 41.7 \\
\hline Degree & 38 & 35.2 \\
\hline Master and above & 5 & 4.6 \\
\hline Total & 100 & 100 \\
\hline
\end{tabular}

The result of the education level indicated that majority of the respondent were people who possessed diploma or NCE educational certificate with a frequency of $46(41.7 \%)$ whereas the least were those with Master degree certificate or above accounting for 5 (4.6\%) 
Table 7 Occupation

\begin{tabular}{|l|l|l|}
\hline Item & Frequency & Percentage\% \\
\hline Civil Servant & 4 & 3.7 \\
\hline Businessman/women & 81 & 75.0 \\
\hline Both & 15 & 13.9 \\
\hline Total & 100 & 100 \\
\hline
\end{tabular}

The results presented in the table above revealed that businessmen/businesswomen respondents were the majority accounting for $81(75.0 \%)$, whereas civil servants were the least, accounting for only $4(3.7 \%)$.

Table 8 Monthly household Income

\begin{tabular}{|l|l|l|}
\hline Item & Frequency & Percentage\% \\
\hline Less than $\$ 5000$ & 4 & 3.7 \\
\hline $5000-9,999$ & 10 & 9.3 \\
\hline $10,000-19,999$ & 13 & 2.0 \\
\hline $20,000-29,999$ & 20 & 18.5 \\
\hline Total & 53 & 49.1 \\
\hline Total above & 100 & 100 \\
\hline
\end{tabular}

The above-illustrated table shown that respondents having $\$ 30,000$ and above as their monthly income were the majority with a frequency of 53 (49.1\%) whereas those with $\$ 5,000-9,999$ were the least with a frequency of $4(3.7 \%)$

\subsubsection{Findings of the Charity based model Islamic Microfinance.}

Table 9 Descriptive Statistics of the Charity based model of Islamic Microfinance (Mean and Standard deviation).

\begin{tabular}{|l|l|l|}
\hline Item & Mean & $\begin{array}{l}\text { Standard } \\
\text { Deviation }\end{array}$ \\
\hline $\begin{array}{l}\text { Q1: Islamic charity based microfinance model can work as a powerful } \\
\text { tool to fight against the impact of Covid-19 on Social wellbeing }\end{array}$ & 4.16 & .762 \\
\hline $\begin{array}{l}\text { Q2: Charitable modes can positively contribute to the socio-economic } \\
\text { background of the poor }\end{array}$ & 4.01 & 1.150 \\
\hline $\begin{array}{l}\text { Q3: Donation funds can facilitate better healthcare facilitates during } \\
\text { the Covid-19 pandemic. }\end{array}$ & 4.38 & .814 \\
\hline $\begin{array}{l}\text { Q4: Charities would absolutely help the livelihood of families during } \\
\text { and after lockdown }\end{array}$ & 4.28 & .712 \\
\hline $\begin{array}{l}\text { Q5: Zakat mode can solve the problem of unemployment by giving } \\
\text { funds to those who lose their business to revitalize the operation }\end{array}$ & 4.04 & .840 \\
\hline $\begin{array}{l}\text { Q6: Waqf model can be viable braising fund to build a center for } \\
\text { healthcare services }\end{array}$ & 4.28 & .7118 \\
\hline $\begin{array}{l}\text { Q7: In overall, the charitable mode could be the most useful mode for } \\
\text { enhancing social wellbeing and economic empowerment }\end{array}$ & 4.22 & .7516 \\
\hline $\begin{array}{l}\text { Q8: In overall, zakat mode could be the most useful mode for } \\
\text { enhancing social wellbeing and economic empowerment }\end{array}$ & 4.00 & .6900 \\
\hline $\begin{array}{l}\text { Q9: In overall, waqf mode could be the most useful mode for } \\
\text { enhancing social wellbeing and economic empowerment }\end{array}$ & 4.18 & .5888 \\
\hline
\end{tabular}


The findings of the descriptive analysis using the means and standard deviation indicated a mean value, which mostly higher than 4.00 as the $\mathrm{Q} 1$ amounted to $(\mathrm{m}=4.16 ; \mathrm{SD}=.762)$. On the other hand, Q2 accounted to $(\mathrm{m}=4.01 ; \mathrm{SD}=1.150)$, while Q3 indicated an $(\mathrm{m}=4.38 ; \mathrm{SD}=.814), \mathrm{Q} 4$ shown $(\mathrm{m}=4.28 ; \mathrm{SD}=.712)$, whereas $\mathrm{Q} 5$ amounted to $(\mathrm{m}=4.04 ; \mathrm{SD}=.840)$. As an attempt to investigate the overall perception of the respondents, Q6 indicated $(\mathrm{m}=4.28 ; \mathrm{SD}=.7118)$, as $\mathrm{Q} 7$ reveals $(\mathrm{m}=4.22 ; \mathrm{SD} .7516)$ as well as $\mathrm{Q} 8(\mathrm{~m}=4.00 ; \mathrm{SD}=.6900)$, and $\mathrm{Q} 9(\mathrm{~m}=4.18 ; \mathrm{SD}=.5888)$.

\subsection{Discussion}

Based on the findings generated from the research, the descriptive test of the demographic distribution of the respondents shows that the majority of the respondents are female, with a percentage of $56.5 \%$, which implies that they patronize the banks more than the male. The age of respondents who participated is within the ages of 18-30 that has the highest percentage of $33.3 \%$, which slightly different from whose ages are from 36-40 While others are less than that. The statistic results also indicated the married respondents are the majority with a percentage of $73.1 \%$. They are likely affected by facing difficulties in meeting basic amenities. Also, $65.7 \%$ are Muslims. Whereas the urban geographical region accounted for 87.0 compared to the rural, which amounted to 5.6. This implies that there is inequality, as the rural people are neglected by the current microfinance banks even most of the banks are situated in the urban region, so it is a necessity to serve the financial needs of the rural people more crucial as the policymakers are encouraged to work actively on institutionalizing Islamic microfinance with special focus on the rural area in the long run. In the short run, funds can be raised through a charity-based model of Islamic microfinance to stabilize social wellbeing equally in both rural and urban regions.

In addition, diploma or NCE holders have a higher percentage of $41.7 \%$ compared to the master's holders of $4.6 \%$. That is, people are unprivileged to further their education even before the Covid19 outbreak. However, $75.0 \%$ of the respondents are a businessman or businesswoman, which constitute that they are tremendously affected by the pandemic, so charity found can be generated to relieve their financial difficulties. The results also revealed that $49.1 \%$ are the respondents with a monthly household income of $\$ 30,000$. This can be translated that their financial situation would not be stable as it was though all the respondents are affected respectively due to the pandemic incidence across all the segments of society.

Furthermore, the findings of the Q1 TO Q2 indicated a high mean value, which is more than 4.00, as well as the Q6 to Q7 that attempted to measure the overall perception, also shown the mean value that is more than 4.00 . This implies that the charity-based model of the Islamic microfinance can absolutely contribute to the eradication of the impact of the Covid-19 on social wellbeing. This finding is line with many studies that revealed a statistically significant effect of Islamic microfinance on socio-economic development, particularly in terms of wellbeing (Irobi, 2008; Muahmmad A.D \& Muhammad A, 2013; Muhammad T \& Mamman. D., 2017; Abdul Khalid, S.N \& Kamaruddin, S.S, 2019; Maikabara, 2020).

\section{CONCLUSION AND RECOMMENDATION}

The study examined the perception of the charity-based model of Islamic microfinance, which comprises of donation, waqf, and zakat for relieving the social wellbeing of the people due to the negatively significant impact posed by Covid-19. The findings revealed that the model is 
applicable for eradicating the impact of Covid-19 on social wellbeing in Nigeria as the descriptive statistical analysis indicated a mean value that is more than 4.00. However, it is recommended that the policymakers and financial institutions work together to employ collective measures for implementing the model to stabilize the social wellbeing across the country. Not only that, the model can be adopted in reenergizing the economic stability by using the funds not just for relieving the wellbeing of the poor and low-income groups but also to finance the business operation of the small and medium enterprises which are deemed to be affected by the Covid-19 outbreak.

\section{REFERENCES}

Abdul Khalid, S.N \& Kamaruddin, S.S. (2019). A Social Performance Management Framework for Islamic Microfinance Institutions. The Journal of Muamalat and Islamic Finance Research, 16(1), 53-69.

Adepoju R.1 \& Oyesanya O.S. (2014). A Critical Analysis of Poverty Alleviation Strategies of Al-Hayat Relief Foundation in Nigeria. Journal of Islamic Finance, 3(No 2), 049-059.

Al-Shami S.S.A, Adbul Majid I.B, Abdul Rashid N. \& Abdul Hamid M.S.R. (2013). Conceptual Framework: The Role of Microfinance on the Wellbeing of Poor People Cases Studies from Malaysia and Yemen. Asian Social Science, 10(1), 1911-2025.

Irobi, C. (2008). Microfinance and Poverty Alleviation: A Case study of Obazu Progressive women association Mberi. Imo State, Nigeria: Uppsala Department of Economics.

Maikabara, A. (2020). Applicability of Islamic microfinance as an alternative tool for poverty eradication in the Kwara state of Nigeria. Unpublished MSc Dissertation, International Islamic University Malaysia.

Mirghani, S. (2011). The war on piracy: Analyzing the discursive battles of corporate and government-sponsored antipiracy media campaigns. Critical Studies in Media Communication, 28(2), 113- 134.

Morduch, J. (1999). The microfinance promises. 1569- 1614. Journal of economic literature, 37(4), 1569- 1614.

Muahmmad A.D \& Muhammad A. (2013). Applicability of Islamic micro-investment Model (IMIM) in Kano state, Nigeria: Empirical evidence. Australian Journal of Basic and Applied Sciences, 7(4), 535- 542.

Muhammad T \& Mamman. D. (2017). Applicability of Islamic Microfinance Bank solution to Poverty Reduction in the Northeast Nigeria. International Journal For Innovative Research and Development, 6(11), 25-31.

Muhammed A.D \& Hassan Z. (2008). Microfinance in Nigeria and the prospects of introducing its Islamic version there in the light of selected Muslim countries' experience. Munich Personal RePEc Archive (MPRA).

Obaidullah, M. \& Khan, T. (2008). Islamic microfinance development: challenges and initiatives.

Obaidullah, M. (2008). Introduction to Islamic microfinance. India: IBF Net (P) Limited. . 
Journal of Islamic Economics Perspectives, Volume 2. Issue 1 (2020)

ISSN 2715-0445 (Online)

Wanchoo, R. (2007). Micro-finance in the India: the changing face of micro-credit Schemes. Munich Personal RePEc Archive (MPRA).

Wilson, R. (2007). Making development assistance sustainable through Islamic Microfinance. International Journal of Economics, Management, and Accounting(15).

Yakubu S.M, Haruna M.A, Mohammed A.I. (2018). Strategies for the Acceptability of Islamic Micro Finance institutions in Nigeria. IOSR Journal of Economics and Finance (IOSR$J E F), 9(6), 71-76$. 